\title{
逐次モンテカルロ法に基づく宇宙機異常診断法*1 一パラメータと異常モードのオンライン同時推定によるアプローチー Spacecraft Fault Diagnosis by Combined Parameter and Mode Online Estimation with Sequential Monte Carlo Methods
}

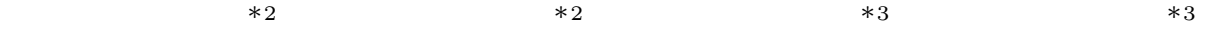 \\ Yoshinobu Kawahara, Kohei Goto, Takehisa YaIri and Kazuo Machida
}

Key Words : Fault Diagnosis, Sequential Monte Carlo Method, Parameter Estimation, Real-Time Monitoring

\begin{abstract}
We propose a new framework for spacecraft fault diagnosis based on combined parameter and mode online estimation using a sequential Monte Carlo method. Our method can detect and diagnose faults as parameter changes and hence can be considered as a probabilistic approach for the parameter-estimation-based fault diagnosis method which is one of the methodologies on quantitative model-based diagnosis. We derive an algorithm for spacecraft fault diagnosis by describing the parameter-estimation-based fault diagnosis method as a probabilistic inference problem and applying a modified sequential Monte Carlo method, obtained by incorporating fault-modes, risk-sensitivities on modes and kernel-smoothing techniques into the original method, to the problem. The proposed fault-diagnosis algorithm was applied to an artificial data simulating malfunctions of thrusters in rendezvous maneuver of spacecraft, and the feasibility of the method was confirmed.
\end{abstract}

記 号 の 説 明

下記の各々の量に関して, 確率変数を $\boldsymbol{X} や \boldsymbol{Y}$ のように 大文字を用いて表し，弚の実現値を $\boldsymbol{x}$ や $y$ のように小文 字を用いて表す．またスカラー量は通常のフォントを用い て表すのに対し，ベクトル量は太字を用いる． 本文中で用いる記号

$$
\begin{aligned}
& \boldsymbol{x}: \text { 状態量 }\left(\in \mathbb{R}^{n_{x}}\right) \\
& \boldsymbol{y}: \text { 観測量 }\left(\in \mathbb{R}^{n_{y}}\right) \\
& \boldsymbol{u}: \text { 制御入力 }\left(\in \mathbb{R}^{n_{u}}\right) \\
& \boldsymbol{\theta}: \text { モデル中のパラメータ } \\
& \boldsymbol{z}: \text { 異常モード (cf. 4.1.1) }
\end{aligned}
$$

$P(\bullet)$ : 確率変数・に関する確率分布

$P\left(\bullet_{1} \mid \bullet_{2}\right): \bullet \bullet_{2}$ を条件とする・1 に関する確率分布

$V(\bullet)$ : 確率変数・に関する分散

$\operatorname{Cov}\left(\bullet_{1}, \bullet_{2}\right)$ : 確率変数 $\bullet_{1}, \bullet_{2}$ 間の共分散

$\mathcal{N}(\bullet ; \boldsymbol{\mu}, V)$ : 確率変数 ・ に関する平均 $\boldsymbol{\mu}$, 分散 $V$ の正規 分布

添え字の説明

$(\cdot)_{t}:$ 時間 $t$ における量

$(\cdot)_{t_{1}: t_{2}}$ : 時刻 $t_{1}$ から $t_{2}$ までに得られたすへての量

$(\cdot)^{(i)}:(\cdot)$ に関する $i$ 番目のパーティクル

*1 C 2007 日本航空宇宙学会

平成 19 年 1 月 9 日原稿受理

*2 東京大学大学院工学系研究科航空宇宙工学専攻

*3 東京大学先端科学技術研究センター
1. 序

論

人工衛星やロケットなどの宇宙機は, 大規模かつ複雑な システムであると同時に, 宇宙環境という特殊な環境下に さらされるため，いかに光の信頼性を確保するかは非常に 重要な問題となる. 近年では, 宇宙ステーションへの自律 ランデブーをはじめ, ミッションの高度化が加速し, 光の 安全性への要求は更に高まっている.

現在多くの運用では, あらかじめ定めたリミット内に值 が入っているかを監視する方法 (limit-value based supervision methods) が主に用いられている.この方法は, シ ンプルで信頼性のある方法であるが, 比較的大きな状況変 化を伴う場合しか扱えず, また詳細な診断は通常不可能で あるという，本質的な限界がある。产のため近年では, 計 算機を用いたより高度な異常診断を行うための方法が研究 あるいは開発されるようになっている．宇宙機の異常診断 方法としては, NASAやJAXA (旧宇宙科学研究所) で は古くからエキスパート・システムに基づく診断システム に関する開発が行われており ${ }^{1 \sim 3)}$ ，また， Remote Agent Experiment ${ }^{4)}$ の一部として Deep Space One に搭載され た NASA のモデルベース診断システム Living Stone ${ }^{5)} に$ 代表される，定性モデルベース診断に基づく診断システム の開発も行われている.特に近年では，より不確実性を明 示的に扱うことが可能な, 確率的なアプローチも研究や開 発が行われるようになってきている ${ }^{6 \sim 10)}$. NASA では, 惑 星ローバーのための逐次モンテカルロ法を用いた異常診断 法についても研究が進められている7). この方法は, 状態 
量の追跡と共に , 事前に想定した離散的なモードを推論し 弚の中でどの異常が発生したのかを判断することにより診 断を行う.

本稿では , 異常時にはシステムを記述する少数のパラメー タが変化するという仮定の下, 状態量に加えてパラメータ, およびパラメータ変化を操作する異常モードを, 同時に逐 次モンテカルロ法を用いてリアルタイムに推定し , 異常検 知および異常診断を行う方法を提案する .この方法では異 常はパラメータ変化としてのみ定義されるため, 得られる 結果は極めて直感的であり，また事前にどのような異常が 発生するかを設定する必要はない，提案する異常診断の枠 組みは, 工学システムの異常診断法の一つである, 定量モ デルベース診断の範疇に含まれるパラメータ推定に基づく 異常診断の枠組みを, 確率推論問題として捉えなおしたア プローチであるとみなすことが可能である .

本稿の構成は，以下のようである．まず 2 章では，提案 する異常診断法の基礎知識として, 状態空間モデルを用い た確率推論，および炎の確率的近似計算法の一つである逐 次モンテカルロ法について概説する . 次に 3 章では, 定量 モデルベース診断の基礎概念を概説すると共に，关の一つ の方法論であるパラメータ推定に基づく異常診断法を確率 推論問題として記述し，4 章において，この確率推論問題 を計算するための定式化を行い, 具体的な異常診断アルゴ リズムを導出する. 光して 5 章では, 導出した診断アルゴ リズム検証のために行った実験に関する，結果および考察 について述べる . 最後に 6 章において，本稿の結論につい て述べる。

\section{2. 逐次モンテカルロ法による確率推論}

本章では, 後述のアルゴリズム導出の背景知識として , ま ず 2.1 において状態空間モデルを用いた確率推論について 述べ，次に 2.2 において产の確率的計算法の一つである逐 次モンテカルロ法について, 本稿に必要な範囲で概説する。

2.1 状態空間モデルを用いた確率推論 宇宙機などの 工学システムの動的特性を記述するモデル表現として，し ばしば次式で表される状態空間モデルが用いられる .

$$
\begin{aligned}
& \boldsymbol{x}_{t}=f\left(\boldsymbol{x}_{t-1}, \boldsymbol{u}_{t}\right)+v_{t} \\
& \boldsymbol{y}_{t}=g\left(\boldsymbol{x}_{t}\right)+w_{t}
\end{aligned}
$$

ここで, $f: \mathcal{X} \times \mathcal{U} \mapsto \mathbb{R}^{n_{x}}$ および $g: \mathcal{X} \mapsto \mathbb{R}^{n_{y}}$ は, 兴れ ぞれ状態の遷移および観測を定める連続関数である．また $v_{t}$ および $w_{t}$ は, 光れ光れシテムノイズおよび観測ノイ ズである . (1a) 式は状態遷移モデル , (1b) は観測モデルと 呼ばれる .このように表される動的システムは, 制御器の 設計などに利用されたり，あるいはモデル化に伴う不確実 性を明示的に表す確率モデルとして表現され, 確率推論に よる状態の追跡や予測などに利用される．

ここでいう確率推論とは, システム $(1)$ を状態遷移確率 分布 $P\left(\boldsymbol{X}_{t} \mid \boldsymbol{X}_{t-1}, \boldsymbol{U}_{t}\right)$ およひ観測確率分布 $P\left(\boldsymbol{Y}_{t} \mid \boldsymbol{X}_{t}\right)$ を 用いて表現し，現在までの観測 $\left(\boldsymbol{y}_{1: T}, \boldsymbol{u}_{1: T}\right)$ から，状態量 に関する事後分布 $P\left(\boldsymbol{X}_{\tau} \mid \boldsymbol{y}_{1: T}, \boldsymbol{u}_{1: T}\right)(\tau \leq T)$ を計算する
問題を意味する .このような問題を解くための最も一般的 な方法論の一つであるベイズフィルターでは, 逐次的に予 測ステップと更新ステップと呼ばれる二つのステップを繰 り返すことで, 前述の事後周辺分布を $\tau=T$ の場合に関し て計算する .より具体的には, まず予測ステップにおいて， 状態遷移分布を用いて事前分布 $P\left(\boldsymbol{X}_{\tau-1} \mid \boldsymbol{y}_{1: \tau-1}, \boldsymbol{u}_{1: \tau-1}\right)$ から予測分布 $P\left(\boldsymbol{X}_{\tau} \mid \boldsymbol{y}_{1: \tau-1}, \boldsymbol{u}_{1: \tau}\right)$ を計算する.

$$
\begin{aligned}
& P\left(\boldsymbol{X}_{\tau} \mid \boldsymbol{y}_{1: \tau-1}, \boldsymbol{u}_{1: \tau}\right) \\
& =\int_{\mathcal{X}_{\tau-1}} P\left(\boldsymbol{X}_{\tau} \mid \boldsymbol{X}_{\tau-1}, \boldsymbol{u}_{\tau}\right) P\left(\boldsymbol{X}_{\tau-1} \mid \boldsymbol{y}_{1: \tau-1}, \boldsymbol{u}_{1: \tau-1}\right) \mathrm{d} \mathcal{X}_{\tau-1}
\end{aligned}
$$

そして更新ステップにおいて，観測分布と新たな観測 $\boldsymbol{y}_{\tau}$ を用いて，予測分布 $P\left(\boldsymbol{X}_{\tau} \mid \boldsymbol{y}_{1: \tau-1}, \boldsymbol{u}_{1: \tau}\right)$ から事後分布 $P\left(\boldsymbol{X}_{\tau} \mid \boldsymbol{y}_{1: \tau}, \boldsymbol{u}_{1: \tau}\right)$ を計算する.

$$
\begin{aligned}
& P\left(\boldsymbol{X}_{t} \mid \boldsymbol{y}_{1: t}, \boldsymbol{u}_{1: t}\right) \\
& \quad=\alpha \cdot P\left(\boldsymbol{y}_{t} \mid \boldsymbol{X}_{t}\right) P\left(\boldsymbol{X}_{t} \mid \boldsymbol{y}_{1: t-1}, \boldsymbol{u}_{1: t}\right)
\end{aligned}
$$

$\alpha$ は正規化係数である .これらの計算には , 線形の場合は カルマンフィルター , 非線形であれば拡張カルマンフィル ター11) や逐次モンテカルロ法 (cf. 2.2) などが適用される.

2.2 逐次モンテカルロ法 逐次モンテカルロ法は, 前述 の確率推論問題における状態量の事後分布計算を行うため の, シミュレーションに基づく近似手法の一つである ${ }^{12,13)}$. この方法は，柔軟で実装や並列化が容易なアルゴリズムで あり，樣々な対象へ適用可能な汎用的枠組みとして知られ ている. システムが非線形である場合には前述の確率推論 計算は厳密には計算不可能であるが, 逐次モンテカルロ法 では, 状態量の事後確率を次式のように重み付けされた $N$ 個のパーティクル ${ }^{* 4} \boldsymbol{x}_{t}^{(i)}$ を用いて近似的に計算する.

$$
P\left(\boldsymbol{X}_{t} \mid \boldsymbol{y}_{1: t}\right) \approx \sum_{i=1}^{N} w_{t}^{(i)} \delta\left(\boldsymbol{x}_{t}, \boldsymbol{x}_{t}^{(i)}\right)
$$

ここで, $\delta(\cdot, \cdot)$ はディラックのデルタ測度である.重み $w_{t}^{(i)}$ は, 重点サンプリングの原理に基づいて選択される ${ }^{12,13)}$. すなわち, 目的となる分布 $P(\boldsymbol{X})$ からのサンプリングが困 難である場合に，サンプリング可能な提案分布*5 $q(\boldsymbol{X})$ を 用いて , 次式のように各サンプルに重みを割り当てる .

$$
w_{t}^{(i)} \propto \frac{P\left(\boldsymbol{x}_{1: t}^{(i)} \mid \boldsymbol{y}_{1: t}\right)}{q\left(\boldsymbol{x}_{1: t}^{(i)} \mid \boldsymbol{y}_{1: t}\right)}
$$

提案分布は $q\left(\boldsymbol{X}_{1: t} \mid \boldsymbol{y}_{1: t}\right)=q\left(\boldsymbol{X}_{t} \mid \boldsymbol{X}_{1: t-1} \boldsymbol{y}_{1: t}\right) q\left(\boldsymbol{X}_{1: t-1} \mid \boldsymbol{y}_{1: t-1}\right)$ のように分解可能な形として与えることが多く，このよう な場合には, 重みも次のように再帰的計算が可能となる .

\footnotetext{
${ }^{* 4}$ i.i.d. (independent and identically distributed) なシミュレー ションにより得られる乱数 . またこの際に行うシミュレーション の各試行は，サンプリングと呼ばれる.

*5 重点分布とも呼ぶ．通常 $q\left(\boldsymbol{x}_{t} \mid \boldsymbol{x}_{t-1}^{(i)}, \boldsymbol{y}_{t}\right)=P\left(\boldsymbol{x}_{t} \mid \boldsymbol{x}_{t-1}^{(i)}\right)$ のよう に事前分布を用いる.この際 (6) 中 $\hat{w}_{t}^{(i)}$ は $P\left(\boldsymbol{y}_{t} \mid \boldsymbol{x}_{t}^{(j)}\right)$ となる
} 
1 for $i=1: N$

$2\left\lfloor\right.$ Sample $\boldsymbol{x}_{0}^{(i)} \sim P\left(\boldsymbol{x}_{0}\right)$ and set $t=1$.

3 for $i=1: N$

$4 \quad$ Sample $\tilde{\boldsymbol{x}}_{t}^{(i)} \sim P\left(\boldsymbol{X}_{t} \mid \boldsymbol{x}_{t-1}^{(i)}, \boldsymbol{u}_{t-1}\right)$.

$5 \quad$ Evaluate the importance weights $\tilde{w}_{t}^{(i)}=P\left(\boldsymbol{y}_{t} \mid \tilde{\boldsymbol{x}}_{t}^{(i)}, \boldsymbol{u}_{t}\right)$.

6 Normalise the importance weights.

7 Resample with replacement $N$ particles $\boldsymbol{x}_{t}^{(i)}(i=1, \cdots, N)$

from the set $\tilde{\boldsymbol{x}}_{t}^{(i)}(i=1, \cdots, N)$ according to $\tilde{w}_{t}^{(i)}$.

8 Set $t \leftarrow t+1$ and go to step 3 .

アルゴリズム 1 Bootstrap Filter

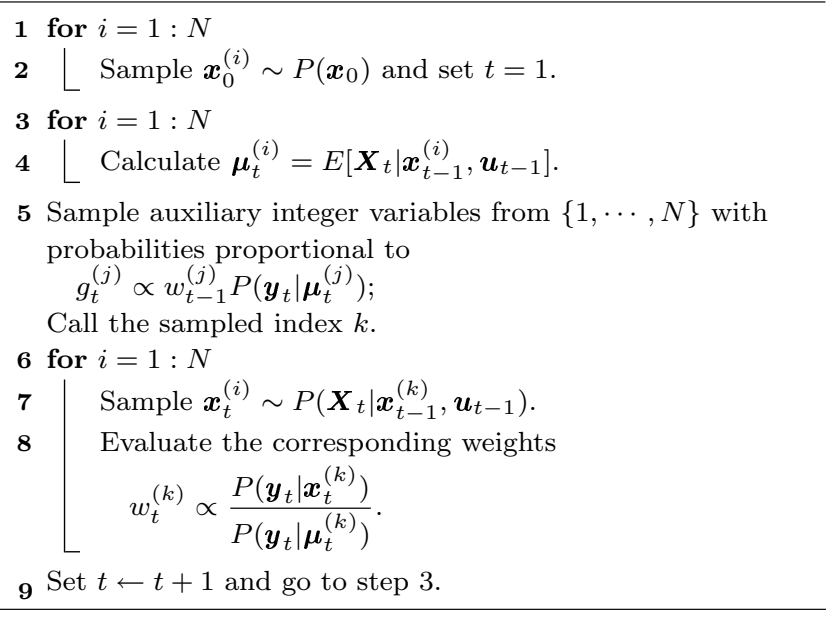

アルゴリズム 2 Auxiliary Particle Filter

$$
\begin{aligned}
w_{t}^{(i)} & \propto \frac{P\left(\boldsymbol{y}_{t} \mid \boldsymbol{x}_{t}^{(i)}\right) P\left(\boldsymbol{x}_{t}^{(i)} \mid \boldsymbol{x}_{t-1}^{(i)}\right) P\left(\boldsymbol{x}_{1: t-1}^{(i)} \mid \boldsymbol{y}_{1: t-1}\right)}{q\left(\boldsymbol{x}_{t}^{(i)} \mid \boldsymbol{x}_{1: t-1}^{(i)}, \boldsymbol{y}_{1: t}\right) q\left(\boldsymbol{x}_{1: t-1}^{(i)} \mid \boldsymbol{y}_{1: t-1}\right)} \\
& =\frac{P\left(\boldsymbol{y}_{t} \mid \boldsymbol{x}_{t}^{(i)}\right) P\left(\boldsymbol{x}_{t}^{(i)} \mid \boldsymbol{x}_{t-1}^{(i)}\right)}{q\left(\boldsymbol{x}_{t}^{(i)} \mid \boldsymbol{x}_{1: t-1}^{(i)}, \boldsymbol{y}_{1: t}\right)} w_{t-1}^{(i)} \\
& \equiv \hat{w}_{t}^{(i)} \times w_{t-1}^{(i)}
\end{aligned}
$$

このような方法は逐次重点サンプリング (SIS) と呼ば れ，光の具体的なアルゴリズムとして最も一般的なもの は，アルゴリズム 1 に示す手順により実行される，Bootstrap Filter である.通常直接 SIS を実行すると時間の 経過と共にパーティクルが縮退してしまうという問題が あるが, Bootstrap Filterでは, 重みの小さいパーティク ルを取り除いて，重みの大きいパーティクルを増殖させる 操作を加えることでこのような問題を解決している*6.ま

${ }^{* 6}$ 再サンプリングと呼ばれる . アルゴリズム 1 中のステップ 7 .

${ }^{* 7}$ この際, APF で推定する同時分布 $P\left(\boldsymbol{X}_{t}, i \mid \boldsymbol{y}_{1: t}\right)$ は

$$
\begin{aligned}
P\left(\boldsymbol{X}_{t}, i \mid \boldsymbol{y}_{1: t}\right) & \propto P\left(\boldsymbol{y}_{t} \mid \boldsymbol{X}_{t}\right) P\left(\boldsymbol{X}_{t}, i \mid \boldsymbol{y}_{1: t-1}\right) \\
& =P\left(\boldsymbol{y}_{t} \mid \boldsymbol{X}_{t}\right) P\left(\boldsymbol{X}_{t} \mid i, \boldsymbol{y}_{1: t-1}\right) P\left(i \mid \boldsymbol{y}_{1: t-1}\right) \\
& =P\left(\boldsymbol{y}_{t} \mid \boldsymbol{X}_{t}\right) P\left(\boldsymbol{X}_{t} \mid \boldsymbol{x}_{t-1}^{(i)}\right) w_{t-1}^{(i)}
\end{aligned}
$$

となるため，各パーティクルの重みは次式のようになる．

$$
w_{t} \propto w_{t-1}^{i^{j}} \frac{P\left(\boldsymbol{y}_{t} \mid \boldsymbol{x}_{t}^{(i)}\right) P\left(\boldsymbol{x}_{t}^{(i)} \mid \boldsymbol{x}_{t-1}^{i^{j}}\right)}{q\left(\boldsymbol{x}_{t}^{(i)}, i^{j} \mid \boldsymbol{y}_{1: t}\right)}=\frac{P\left(\boldsymbol{y}_{t} \mid \boldsymbol{x}_{t}^{(i)}\right)}{P\left(\boldsymbol{y}_{t} \mid \boldsymbol{\mu}_{t}^{i^{j}}\right)}
$$

*8 定量モデルベース診断以外にも, 異なる原理に基づいた有用な異 常診断アプローチが樣々提案されている.これらの概要および定 量モデルベース診断の位置づけに関しては, 文献 16) 等を参照 .
た提案分布を $q\left(\boldsymbol{X}_{t}, i \mid \boldsymbol{y}_{1: t}\right)$ と選択し, $\left\{\boldsymbol{x}_{t}^{(i)}, i^{j}\right\}\left(i^{j}\right.$ は時 刻 $t-1$ におけるパーティクルのインデックス) の組を サンプリングすることにより, Bootstrap Filter と比べて より真の状態に近いパーティクルを生成することを実現す る Auxiarity Particle Filter (APF) ${ }^{14)}$ というアルゴリズ ムも提案されている (cf. アルゴリズム 2) . APF で用い る提案分布 $q\left(\boldsymbol{X}_{t}, i \mid \boldsymbol{y}_{1: t}\right)=q\left(i \mid \boldsymbol{y}_{1: t}\right) q\left(\boldsymbol{X}_{t} \mid i, \boldsymbol{y}_{1: t}\right)$ は, 通 常 $q\left(\boldsymbol{X}_{t} \mid i, \boldsymbol{y}_{1: t}\right) \equiv P\left(\boldsymbol{X}_{t} \mid \boldsymbol{x}_{t-1}^{(i)}\right)$ および $q\left(\boldsymbol{X}_{t}, i \mid \boldsymbol{y}_{1: t}\right) \propto$ $P\left(\boldsymbol{y}_{t} \mid \boldsymbol{\mu}_{t}^{(i)}\right) P\left(\boldsymbol{X}_{t} \mid \boldsymbol{x}_{t-1}^{(i)}\right) w_{t-1}^{(i)}\left(\boldsymbol{\mu}_{t}^{(i)}=E\left[\boldsymbol{X}_{t} \mid \boldsymbol{x}_{t-1}^{(i)}\right]\right)$ として 定義され，サンプリングを行う分布は最終的に $q\left(i \mid \boldsymbol{y}_{1: t}\right) \propto$ $P\left(\boldsymbol{y}_{t} \mid \boldsymbol{\mu}_{t}^{(i)}\right) w_{t-1}^{(i)}$ となる (アルゴリズム 2 中ステップ 5$)^{* 7}$. このように APF では, 前時刻 $t-1$ におけるパーティク ルから直接的なサンプル生成が可能となり, 精度向上が期 待できることが知られている .

\section{3. 確率推論問題としての異常診断}

定量モデルベース診断の方法論の一つであるパラメータ 推定による異常診断 (以後, パラメータ推定法と呼ぶ）は， パラメータ推定を伴う確率推論問題として扱うことが可能 である . 本章では, まず 3.1 において定量モデルベース診 断とパラメータ推定法について概説し，続く 3.2 において， パラメータ推定法を確率推論問題として記述する.

3.1 定量モデルベース診断とパラメータ推定法 工学 システムの異常診断に関する研究・開発は, 1970 年代前半 頃から盛んに行われているが, 宇宙機のように, 数式で表 現可能な解析モデルが豊富な対象への応用では, 定量モデ ルベース診断と呼ばれるアプローチが有用である場合が多 い*8. 一般に定量モデルベース診断では, 第 1 図に示すよ うに, 数式を用いて表される各コンポーネントに関する診 断モデルを用いて, 異なる複数の観測間の依存関係からプ ロセスやアクチュエータ,センサー内の異常を検知する ${ }^{15)}$. その主な方法論としては, オブザーバーに基づく方法や , パ ラメータ推定による方法, およびパリティ方程式を用いた 方法などが含まれ，問題に応じて光れ適用される．

オブザーバーやパリティ方程式に基づく方法がモデル中 のパラメータはあらかじめ既知であるとして観測や入力間 の偏差から異常を検知するのに対し, パラメータ推定法で は, パラメータ产のものを推定することにより, 光の変化 から異常を検知する．つまりパラメータ推定法では，第 2 図に表されるように, プロセスやアクチュエータ,センサー

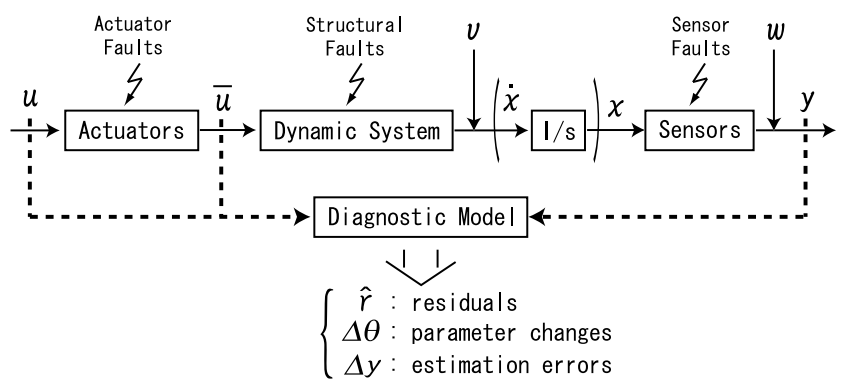

第 1 図 定量モデルベース診断による動的システムの異常診断 


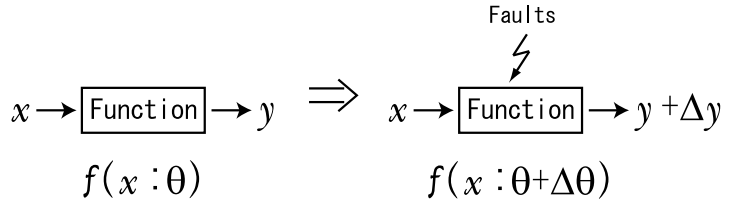

第 2 图 パラメータ推定法に用いられる異常モデル

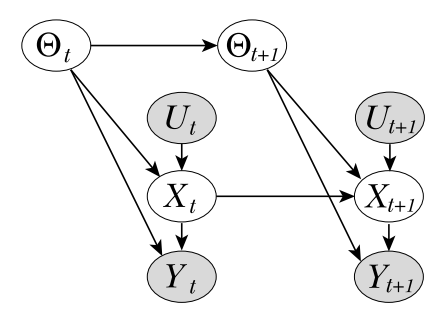

第 3 図 パラメータ推定を伴う確率推論に用いる状態空間モデル

各コンポーネントに生じる異常が有限個のパラメータ変化 に起因すると仮定し，観測から弚のパラメータ変化を推定 することで異常検知を行う．従って， システムに関するあ る程度正確なモデルを与えることが必要となるが, 光のよ うなモデルが得られる場合には，この方法に基づく診断結 果は極めて直感的であり，有用な場合が多い．

3.2 確率推論問題としてのパラメータ推定法 パラメー 夕推定に基づく異常診断法は, パラメータ推定を伴う確率 推論問題として扱うことが可能である.通常，2.1で述べた 確率推論においては, 各確率分布のパラメータはあらかじ め既知であるとして，一定な定数として扱われる．しかし 本稿では, 上述のように異常診断を目的としてパラメータ 推定を同時に行うため, 対象となる一部のパラメータは非 定常であるとして扱う.つまり, 状態量に加えてパラメータ も含む事後周辺分布 $P\left(\boldsymbol{X}_{\tau}, \boldsymbol{\Theta}_{\tau} \mid \boldsymbol{y}_{1: T}, \boldsymbol{u}_{1: T}\right)$ を逐次的に計 算する. 従って, 状態遷移分布 $P\left(\boldsymbol{X}_{t+1} \mid \boldsymbol{X}_{t}, \boldsymbol{U}_{t}, \boldsymbol{\Theta}_{t}\right)$ およ び観測分布 $P\left(\boldsymbol{Y}_{t} \mid \boldsymbol{X}_{t}, \boldsymbol{\Theta}_{t}\right)$ に加え，パラメータの時間的遷 移を表す条件付き確率分布 $P\left(\boldsymbol{\Theta}_{t+1} \mid \boldsymbol{\Theta}_{t}\right)$ を明示的に与え る必要がある (cf. 第 3 図 ${ }^{* 9}$ ). この際, 通常定常であるパ ラメータを人為的に励起する方法の一つは，各時間におい て白色ノイズ $\boldsymbol{\xi}_{t} \sim \mathcal{N}\left(0, V\left(\boldsymbol{\xi}_{t}\right)\right)$ を加えて, $\boldsymbol{\theta}_{t+1}=\boldsymbol{\theta}_{t}+\xi_{t}$ としてパラメータを更新するというものである .つまりこ の場合 , パラメータの遷移分布は次式のようになる .

$$
P\left(\boldsymbol{\Theta}_{t+1} \mid \boldsymbol{\Theta}_{t}\right)=\mathcal{N}\left(\boldsymbol{\Theta}_{t+1} ; \overline{\boldsymbol{\theta}}_{t}, V\left(\boldsymbol{\Theta}_{t}\right)+V\left(\boldsymbol{\xi}_{t}\right)\right)
$$

ここで $\overline{\boldsymbol{\theta}}_{t}$ は $\Theta_{t}$ の平均値である .このようなモデルを用い て, 状態量に加えてパラメータをリアルタイムで同時に推 定することで, 本来一定であるパラメータの正常時からの 偏差として，異常を検知することが可能となる．更に，ど のパラメータか変化したかを見ることで異常個所を特定し

*9 このようなグラフ構造は, 確率モデルを表現するためにしばしば 用いられる.グラフ中, 黑ノードは観測可能な変数, 白ノードは 観測不可能な変数 (隠れ変数) を表す. また弧によって表される 構造により, 各変数は自分を到達ノードとする弧の出発ノードに のみ依存する, という変数間の条件付き独立性が表現されている．
たり, 弚のパラメータの変化の状態から異常状態を推定す ることが可能となる．ただし，この推論問題を計算するの は一般に非常に困難である . 本稿では, 次章でこの問題を 解くための推論アルゴリズムを導出する．

\section{4. パラメータ・モード 同時推定による異常診断法}

本節では, 前節で述べたパラメータ推定を伴う確率推論 問題を計算するためのアルゴリズムを導出する . まず 4.1 では, この確率推論問題へ直接逐次モンテカルロ法を適用 した場合の問題点を提起し，光の具体的な解決方法につい て述べる.弚して $4.2 て ゙ は ， 4.1$ で述べる内容を基に，具体 的な推論アルゴリズムを導出する．

4.1 問題点とその解決方法 3.2 で述べたパラメータ推 定を伴う確率推論問題に対して，一般的な逐次モンテカル ロ法の推論アルゴリズムを適用するには，相乗的な次の二 つの問題点が挙げられる.まずパラメータ推定を伴う場合 に共通の問題であるが, 状態量に加えてパラメータも同時 に推定する必要があるため, 探索空間が大幅に増加してし まうという点である．従ってこれらを正確に同時推定する ためには, 莫大な数のパーティクルが必要となる.更に異常 診断独特の問題として, 光も光も異常が発生する確率は非 常に低確率であるという点である．つまり，通常の逐次モン テカルロ法では, 状態の事後確率に従いサンプリングを行 うため, 発生する確率が極めて低い異常状態に関するパー ティクルの数は非常に少なくなり, 兴の少数のパーティク ルでパラメータ推定を行わなければならなくなってしまう．

乥こで本研究では, これらの問題を解決するためにいく つかの技術的な改良を加えることにより，前述のパラメー 夕推定を伴う推論問題を計算する。まず, 異常発生の独立 性，つまり異常が同時に複数発生することは非常に稀であ るという仮定を利用する方法として，4.1.1において異常 モードを導入する.更に4.1.2では，光の異常モード上で の“リスク”を組み込む .この異常モード・リスクは, サン プリングする事後確率にバイアスをかけ，低確率下で発生 する異常状態に関するパーティクルがサンプリングされや すいように機能する．また 4.1 .3 では , パラメータ推定の 発散を防ぐためにカーネル平滑化を利用する方法について 述べる。

4.1.1 異常モードの導入 前述のように,パラメータ推 定に伴う探索空間の増大を削減するため, 本研究では, 異 常モードを導入することにより異常の独立性を利用する． 異常モードの定義は, 次のように与えられる .

定義 1 (異常モード) 推定対象となるパラメータ $\boldsymbol{\theta}$ が 与えられたとき, 異常モード $\boldsymbol{z}$ は, 次のような条件を満た す離散確率変数として定義される .

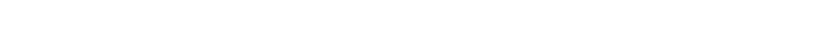
パラメータか割り当てられる.

·各モードのとり得る値は, 0 (正常) または 1 (異常) の 2 值のみであり $(z=0$ or 1$)$, 各々割り当てられたパラ メータに対して次のような影響を与える。

- 0 : パラメータカ時間と共に変化しない。 


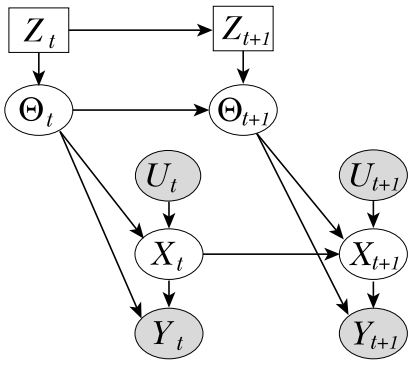

第 4 図＼cjkstart異常診断に用いる状態空間モデル

- 1 : パラメータか時間と共に変化する .

一つ目の条件は, 異常の独立性を具体的に表現するための ものである.つまり，すべてのパラメータに影響を与える異 常というのは通常極めて稀で, 例えば宇宙機の複数のスラ スタの異常診断を行う必要がある場合を考えると，同時に すべてのスラスタが異常になるというのは考えにくく，ど れか一つ，あるいは必要であれば同時に二つのスラスタが 異常になる可能性があると考えれば十分である．光して二 つ目の条件により，第 2 図で表される，パラメータ偏差と しての異常を具体的に表現する．つまりある異常が発生し た場合には, 弚れに関連するパラメータ(これは一つ目の条 件により定められる) のみが, 正常時の規定値からの逸脱 を開始する。より具体的には， $\theta_{i}$ を異常モード $z_{j}$ に割り 当てられたパラメータとするとき，次式のように表される

$$
P\left(\Theta_{t+1, i} \mid \theta_{t, i}, \boldsymbol{z}_{t, j}\right) \sim\left\{\begin{array}{cc}
\mathcal{N}\left(\underline{\theta}_{i}, V_{0}\right), & z_{t, j}=0 \\
\mathcal{N}\left(\theta_{t, i}, V_{1}\right), & z_{t, j}=1
\end{array}\right.
$$

ここで, $\underline{\theta}_{i}$ はパラメータ $\theta_{i}$ の規定值であり，また $V_{0}$ お よび $V_{1}$ は各々正常時および異常時のパラメータ遷移に伴 う分散行列であり， $V_{0} \ll V_{1}$ として設定する . 正常時にも 分散 $V_{0}$ を与えて, 一定な平均值を持つ分布からサンプリ ングを行うのは, 状態の遷移分布にシステムノイズを与え るのと同等の理由であり，パラメータの縮退を防ぐためで ある.この異常モードを導入することにより，パラメータ 推定に必要となる探索空間は, 例えば各々のモードに一つ のパラメータカ割り当てられた場合には $\mathbb{R}^{n_{p}}$ から $n_{p} \times \mathbb{R}$ となるように, 飛躍的に減少する．なお，異常モードを導 入した場合の状態空間モデルのグラフ表現は, 第 4 图のよ うになる.この場合のように, 離散変数 (モード)を起点と して状態の遷移が決まる状態空間モデル (一般にスイッチ ング・モデルなどと呼ばれる) は, 時間の経過と共に離散的 な状態力指数関数的に増加するため(離散值の数を $K$ とす ると $\left.\varnothing\left(K^{t}\right)\right)$, 拡張カルマンフィルタのような厳密推論に 基づく方法では計算が困難であることが知られている ${ }^{17)}$.

4.1 .2 異常モード・リスクの導入 通常の逐次モンテカ ルロ法では, 状態の事後確率のみに比例してパーティクル が生成される. 従って, 異常のように非常に低確率で稀に しか発生しない状態は極少数のパーティクルのみで追尾さ れることとなるため，このような状態を正確に追跡して異
常を迅速に検知するためには，膨大な数のパーティクルが 必要となってしまう.乥こで本研究では，このような異常 発生の低確率性を克服するための工夫として，モードに対 する“リスク”という概念を導入する．リスクを導入した逐 次モンテカルロ法は Thrun らにより Risk Sensitive Particle Filters (RSPFs) として提案されており18)，ここでは RSPFs を前述の診断モデルに適した形で適用する．

一般にRSPFs では, 状態の事後確率 $P\left(\boldsymbol{X}_{\tau} \mid \boldsymbol{y}_{1: T}, \boldsymbol{u}_{1: T}\right)$ からでなく, 次式のように, 事後確率と, 状態に依存する リスク関数 $r\left(\boldsymbol{x}_{t}\right)$ の積からサンプリングを行う .

$$
\gamma_{t} r\left(\boldsymbol{x}_{\tau}\right) P\left(\boldsymbol{X}_{\tau} \mid \boldsymbol{y}_{1: T}, \boldsymbol{u}_{1: T}\right)
$$

ここで $\gamma_{t}=\left[\int r\left(\boldsymbol{x}_{t}\right) P\left(\boldsymbol{X}_{\tau} \mid \boldsymbol{y}_{1: T}, \boldsymbol{u}_{1: T}\right) \mathrm{d} \boldsymbol{X}\right]^{-1}$ は正規化係 数である.このようにサンプリングを行うことで, 計算リ ソース (つまりパーティクル) を状態のリスクに応じてバイ アスをかけて分配する効果がある .このようなサンプリン グは, 通常の逐次モンテカルロ法において, 次の二つの変 更を行うことのみで可能となる．まず一つは，初期時刻に おける状態量のサンプリング (アルゴリズム 1 および 2 の ステップ 1,2$)$ を行う分布を, 次の分布に置き換える必要 がある .

$$
\gamma_{0} r\left(\boldsymbol{x}_{0}\right) P\left(\boldsymbol{X}_{0}\right)
$$

乥してもう一つの変更点として , アルゴリズム 1 および 2 の ステップ 5 において計算する, 各サンプルの重点重み $\tilde{w}_{t}^{(i)}$, あるいは補助重み $g_{t}^{(i)}$ を次式のように置き換える必要が ある

$$
\begin{aligned}
& \tilde{w}_{t}^{(i)}=r\left(\boldsymbol{x}_{t}^{(i)}\right) / r\left(\boldsymbol{x}_{t-1}^{(i)}\right) \cdot P\left(\boldsymbol{y}_{t} \mid \boldsymbol{x}_{t}^{(i)}\right) \\
& g_{t}^{(i)} \propto w_{t-1}^{(i)} r\left(\boldsymbol{x}_{t}^{(i)}\right) / r\left(\boldsymbol{x}_{t-1}^{(i)}\right) \cdot P\left(\boldsymbol{y}_{t} \mid \boldsymbol{x}_{t}^{(i)}\right)
\end{aligned}
$$

リスク関数 $r\left(\boldsymbol{x}_{t}\right)$ は明示的に設定する必要があるが, こ こでは単純に, 異常である場合はリスクが高く, 逆に正常 である場合はリスクが低いとして設定する．つまり，本研 究で用いる診断モデルでは異常に関する情報はすべて異常 モード $z_{t}$ か持っているので, リスク関数は $z_{t}$ のみに依存 する関数として与え, $r\left(\boldsymbol{z}_{t}^{i}=\right.$ 正常 $) \ll r\left(\boldsymbol{z}_{t}^{i}=\right.$ 異常 $)$ とし て設定する .これにより，(9) 式に応じたサンプリングが可 能となり，低確率で発生する異常状態の追跡が可能となる．

4.1.3 パラメータ推定におけるカーネル平滑化 前述の ように，本来一定であるパラメータを推定するためには, パ ラメータを人為的に励起する必要がある. 产の際，(7) 式の ように単に白色ノイズを加えるだけでは，パラメータに関 する分散が時間と共に増加する一方になり，推定が非常に 困難になってしまう．このような“情報の損失”を防ぐため の方法として，次のように,パラメータに関するパーティク ルにカーネル平滑化を利用することが可能である ${ }^{12,19,20)}$.

逐次モンテカルロ法において (7) 式のように白色ノイズ

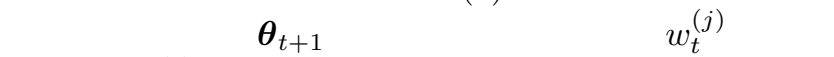
ティクル $\theta_{t}^{(j)}$ を用いて次式のように近似することと等価で ある。 


$$
P\left(\boldsymbol{\Theta}_{t+1} \mid \boldsymbol{y}_{1: t}\right) \approx \sum_{j=1}^{N} w_{t}^{(j)} \mathcal{N}\left(\boldsymbol{\Theta}_{t+1} \mid \boldsymbol{\theta}_{t}^{(j)}, h^{2} V_{t}\right)
$$

ここで, $V_{t}$ は時刻 $t$ におけるパーティクルから計算したパ ラメータの分散であり，また $h(>0)$ は加えるノイズから 決まる.パーティクルに関する分散值は, 時刻 $t+1$ におい て $\left(1+h^{2}\right) V_{t}$ のように増加してしまう．乥こで，パーティ クル $\theta_{t}^{(j)}$ を弚のまま用いるのではなく, より縮退したパー ティクル $\boldsymbol{m}_{t}^{(j)}$ を用いて, 次式のように分布を近似する.

$$
P\left(\boldsymbol{\Theta}_{t+1} \mid \boldsymbol{y}_{1: t}\right)=\sum_{j=1}^{N} w_{t}^{(j)} \mathcal{N}\left(\boldsymbol{\Theta}_{t+1} \mid \boldsymbol{m}_{t}^{(j)}, h^{2} V_{t}\right)
$$

この際, 縮退したパーティクルは, 次式のように定められる

$$
\boldsymbol{m}_{t}^{(j)}=a \boldsymbol{\theta}_{t}^{(j)}+(1-a) \overline{\boldsymbol{\theta}}_{t}
$$

ここで $\overline{\boldsymbol{\theta}}$ は $\boldsymbol{\theta}_{t}^{(j)}$ の平均値,$a=\sqrt{1-h^{2}}$ である.結果と して, $\boldsymbol{\theta}_{t+1}$ に関する分布は時刻 $t$ の時と同じく $V_{t}$ とな $ろ^{* 10}$.

4.2 診断アルゴリズム これまでに述べた内容を元に 導いた異常診断アルゴリズムは，アルゴリズム 3 のように なる.基本的には APF (アルゴリズム 2) と同樣の手順で 実行可能であるが, 状態量に加え , パラメータおよび4.1.1 で述べた異常モードを推定対象とし，4.1.2 で述べた異常 モード上のリスク , 4.1 .3 で述べたパラメータ推定における カーネル平滑化を加えたものとなっている．異常モード . リスクは, ステップ 2 における初期モードのサンプリング とステップ 7 における補助重みの計算に, カーネル平滑化 は, ステップ 6 において事前点推定を行う点に反映されて いる.本アルゴリズムにより，推定される異常モードの実 現確率 (すなわち $P\left(\boldsymbol{z}_{t}^{i}\right)=$ 異常)，および推定されるパラ

*10 このような操作は, 観測 $\boldsymbol{y}_{1: t}$ を与えた時のノイズ $\boldsymbol{\xi}_{t}$ が , 白色 ノイズではなく, パラメータ $\boldsymbol{\theta}_{t}$ と相関を持つ有色ノイズである と仮定していることに相当する.つまり，時刻 $t+1$ における $\boldsymbol{\theta}$ に関する分散が，次式のように与えられると仮定している .

$$
V\left(\boldsymbol{\theta}_{t+1} \mid \boldsymbol{y}_{1: t}\right)=V\left(\boldsymbol{\theta}_{t} \mid \boldsymbol{y}_{1: t}\right)+W_{t+1}+2 \operatorname{Cov}\left(\boldsymbol{\theta}_{t}, \boldsymbol{\xi}_{t+1} \mid \boldsymbol{y}_{1: t}\right)
$$

このとき, パラメータに関する分散が時間と共に一定，つまり $V\left(\boldsymbol{\theta}_{t+1} \mid \boldsymbol{y}_{1: t}\right)=V\left(\boldsymbol{\theta}_{t} \mid \boldsymbol{y}_{1: t}\right)=V_{t}$ とするには, ノイズ $\boldsymbol{\xi}_{t}$ とパラ メータ $\boldsymbol{\theta}_{t}$ の事後共分散を, $\operatorname{Cov}\left(\boldsymbol{\theta}_{t}, \xi_{t+1} \mid \boldsymbol{y}_{1: t}\right)=-W_{t+1} / 2$ の ように与えればよいことがわかる .このようなノイズとパラメー タの負の相関を与えると, 時刻 $t+1$ におけるパラメータの条件 付き分布は，次式のように与えられる .

$$
P\left(\boldsymbol{\theta}_{t+1} \mid \boldsymbol{\theta}_{t}\right)=\mathcal{N}\left(\boldsymbol{\theta}_{t+1} \mid A_{t+1} \boldsymbol{\theta}_{t}+\left(I-A_{t+1}\right) \overline{\boldsymbol{\theta}}_{t},\left(I-A_{t+1}^{2}\right) V_{t}\right)
$$

$A_{t+1}=I-W_{t+1} V_{t}^{-1} / 2$ である .このとき, $W_{t+1}=V_{t}(1 / \delta-$ 1), $A_{t+1}=a I(A=(3 \delta-1) / 2 \delta)$ として与えると, 上記の分布 は次式のようになり，(14) および (15) 式と同樣になることがわ かる.

$$
P\left(\boldsymbol{\theta}_{t+1} \mid \boldsymbol{\theta}_{t}\right)=\mathcal{N}\left(\boldsymbol{\theta}_{t+1} \mid a \boldsymbol{\theta}_{t}+(1-a) \overline{\boldsymbol{\theta}}_{t}, h^{2} V_{t}\right)
$$

*11 本シミュレーションは, Princeton Satellite Systems 社によっ て販売されている MATLAB ソフトウェア Spacecraft Control Toolbox (www.psatellite.com/products/html/sct.php) を用い て作成したものである .

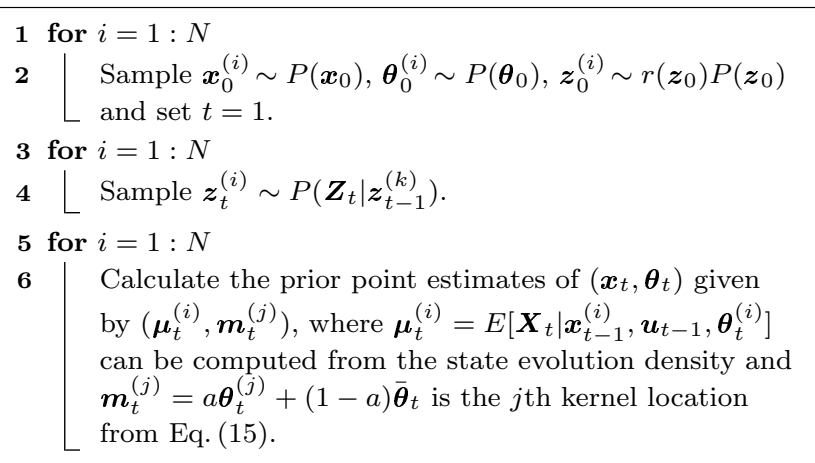

7 Sample auxiliary integer variables from $\{1, \cdots, N\}$ with probabilities proportional to

$$
g_{t}^{(j)} \propto w_{t-1}^{(j)} r\left(\boldsymbol{z}_{t}^{(j)}\right) / r\left(\boldsymbol{z}_{t-1}^{(j)}\right) P\left(\boldsymbol{y}_{t} \mid \boldsymbol{\mu}_{t}^{(j)}, \boldsymbol{m}_{t}^{(j)}\right)
$$

Call the sampled index $k$.

8 for $i=1: N$

$$
\begin{array}{r|l}
\mathbf{9} & \text { Sample } \boldsymbol{\theta}_{t}^{(i)} \sim P\left(\boldsymbol{\Theta}_{t} \mid \boldsymbol{\theta}_{t-1}^{(k)}, \boldsymbol{z}_{t}^{(i)}\right) . \\
\mathbf{1 1} & \text { Sample } \boldsymbol{x}_{t}^{(i)} \sim P\left(\boldsymbol{X}_{t} \mid \boldsymbol{x}_{t-1}^{(k)}, \boldsymbol{u}_{t-1}, \boldsymbol{\theta}_{t}^{(i)}\right) . \\
& \text { Evaluate the corresponding weights } \\
& w_{t}^{(k)} \propto \frac{P\left(\boldsymbol{y}_{t} \mid \boldsymbol{x}_{t}^{(k)}, \boldsymbol{u}_{t}\right)}{P\left(\boldsymbol{y}_{t} \mid \boldsymbol{\mu}_{t}^{(k)}, \boldsymbol{u}_{t}\right)} .
\end{array}
$$

12 Set $t \leftarrow t+1$ and go to step 3 .

アルゴリズム 3 提案する異常診断アルゴリズム

メータの正常時からの逸脱を追うことで, リアルタイムで の異常検知, 更には異常個所の特定や状況の把握などの異 常診断が可能となる.なお, 次章において, 本アルゴリズ 么の具体的問題への適用方法や適用例について述べる.

\section{5. 検 証 実 験}

本実験は , 宇宙機のランデブー・プロセスにおけるスラ スタ異常を模擬したシミュレーション・データを用いて行っ た . 実験では, スラスタ異常の検知と, 異常スラスタの特 定，および炎の推力低下の推定を目的としたものである. 本節では, まず 5.1 において本実験に用いるデータ生成の ために行ったシミュレーション概要を述べ, 5.2 において本 実験における提案手法の事前設定について述べる . 光して 5.3 では, 本実験の適用結果と光の考察について述べる.

5.1 シミュレーション概要 ランデブーを行う宇宙機 は，14 機のスラスタを用いて姿勢および並進制御を行い， データはこのスラスタへの 16 段階のコマンド 14 系列 $(\boldsymbol{u})$ と, 宇宙機の状態 (位置, 速度, 姿勢角, 角速度) の観測系 列 12 系列 $(\boldsymbol{y})$ の, 計 26 系列から成る.データは 0.125 秒 間隔で，1000 秒間のシミュレーションとなっている*11. 用 いた運動方程式は, 次式で表されるヒルの方程式 (16) とオ イラー方程式 (17) である .

$$
\begin{aligned}
& \ddot{r}_{x}=2 n \dot{r}_{z}+T_{x} \\
& \ddot{r}_{y}=-n^{2} r_{y}+T_{y} \\
& \ddot{r}_{z}=3 n^{2} r_{z}-2 n \dot{r}_{x}+T_{z}
\end{aligned}
$$



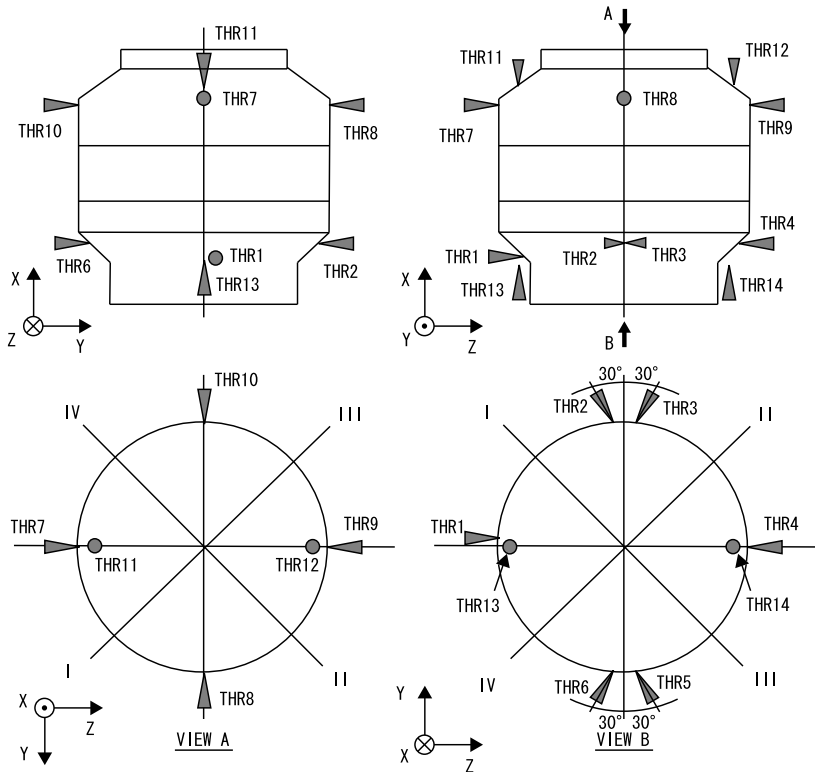

第 5 図 スラスタの配置

$$
\begin{aligned}
I_{x} \dot{\omega}_{x}+n\left(I_{y}-I_{z}\right) \omega_{z} & =M_{x} \\
I_{y} \dot{\omega}_{y} & =M_{y} \\
I_{z} \dot{\omega}_{z}-n\left(I_{x}-I_{y}\right) \omega_{x} & =M_{z}
\end{aligned}
$$

ここで, $r_{i}, \omega_{i}, T_{i}, M_{i}$ および $I_{i}(i=x, y, z)$ は各軸に関 する並進距離，角速度，並進力，モーメン卜，およひ慣性 モーメントであり， $n$ は円軌道平均運動である．また，各 軸周りのオイラー角に関する方程式は, 次式で表される .

$$
\dot{\boldsymbol{\theta}}=\left[\omega_{x}+n \theta_{z}, \omega_{y}+n, \omega_{z}-n \theta_{x}\right]^{\mathrm{T}}
$$

シミュレーションに用いた宇宙機は総重量 $15,000[\mathrm{~kg}]$ であり，慣性モーメントは $I_{x}=33,000, I_{y}=I_{z}=$ $120,000\left[\mathrm{~kg} \cdot \mathrm{m}^{2}\right]$, 弚の重心は $(5300,0,0)[\mathrm{mm}]$ である. ま た各スラスタの推力は $120[\mathrm{~N}]$ であり，弚の配置は第 5 図の ように仮定した．姿勢および並進運動は各々フィードバッ ク制御されており，目標姿勢 $\left(\theta_{i}=0\right)$ および目標相対位置 $\left(x=y=0, z=z_{c}\right)$ 付近に保たれている (ランデブーは $-z$ 方向であり， $z_{c}$ (各時刻で指定) .この際，制御は目標 からのずれが一定値より大きくなった場合に，各状態量ご とに第 1 表に示すスラスタを用いて行われる.ずれから各 スラスタへの要求パルス幅への変換は, 内点法を用いて最 適化計算される.

なお第 6 図は，正常にランデブーが行われた場合の各ス ラスタへのコマンド入力である.$-z$ 方向への制御に用い られる, スラスタ\#4および\# 9 が他のスラスタに比べて多 用されており，最も重要なスラスタであると言える．

5.2 設定について 前編で導出した診断アルゴリズム 実行のためには，いくつかのパラメータを設定する必要 がある．まず一つは，4.1.1で導入した異常モード遷移確 率 $P\left(z_{t}^{i} \mid z_{t-1}^{j}\right)$ である. 基本的には, 正常から正常または

\begin{tabular}{|c|c|c|c|c|c|c|c|c|c|c|}
\hline & $\phi$ & $\theta$ & \multicolumn{2}{|c|}{$\psi$} & \multicolumn{2}{|c|}{$x$} & \multicolumn{2}{|c|}{$y$} & \multicolumn{2}{|c|}{$z$} \\
\hline & $+\quad-$ & $+\quad-$ & + & - & + & - & + & - & + & - \\
\hline 1 & & O & & & & & & & 0 & \\
\hline 2 & 0 & & C & & & & & 0 & & \\
\hline 3 & 0 & & C & & & & & O & & \\
\hline 4 & & C & & & & & & & & 0 \\
\hline 5 & 0 & & & 0 & & & 0 & & & \\
\hline 6 & 0 & & & 0 & & & 0 & & & \\
\hline 7 & & C & & & & & & & 0 & \\
\hline 8 & & & & 0 & & & & 0 & & \\
\hline 9 & & 0 & & & & & & & & 0 \\
\hline 10 & & & c & & & & 0 & & & \\
\hline 11 & & & & & & 0 & & & & \\
\hline 12 & & & & & & 0 & & & & \\
\hline 13 & & & & & 0 & & & & & \\
\hline 14 & & & & & 0 & & & & & \\
\hline
\end{tabular}
異常，異常から正常または異常，の四つの遷移確率を設定 すればよい . 異常から正常への遷移は現実的には考えにく
第 1 表 スラスタの使用表

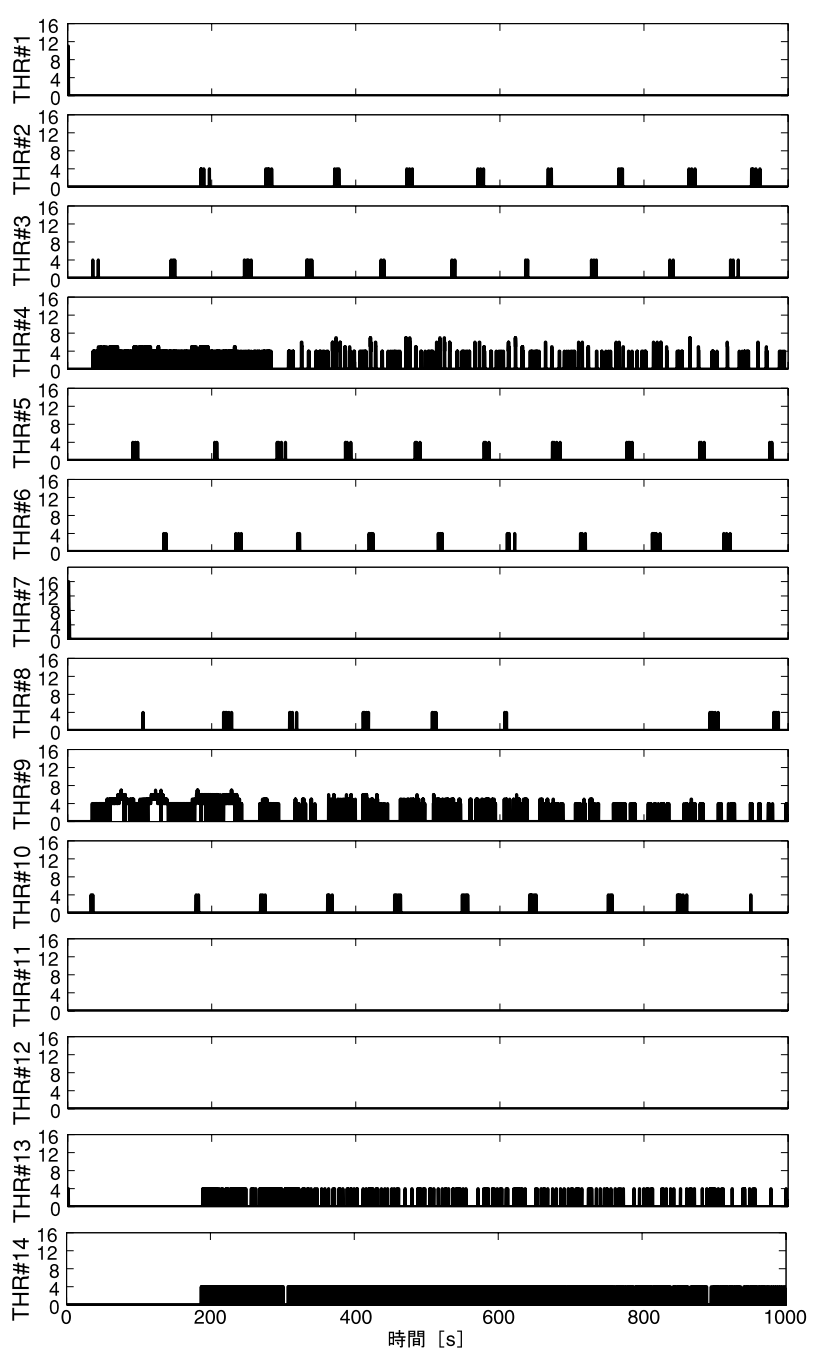

第 6 図 正常なランデブー時の各スラスタへのコマンド入力

いが，実用上 0 でない確率を設定する必要がある。なぜ なら，正常と異常が等価となる場合に(例えば今回の場合 ではスラスタを噴かなければ，異常と正常の区別はできな (い)，正常から異常へパーティクルがすべて移ってしまうの を防ぐためである．次に，4.1.2で述べた各モードのリスク 


\begin{tabular}{ll}
\multicolumn{1}{c}{ 第 2 表 } & 実験の事前設定 \\
\hline 異常モード・リスク & $r\left(z_{t}^{i}=\right.$ 正常 $)=0.8$ \\
& $r\left(z_{t}^{i}=\right.$ 異常 $)=10.0$ \\
異常モード遷移確率 & $P\left(z_{t}^{i}=\right.$ 正常 $\mid z_{t}^{i}=$ 正常 $)=1.0$ \\
& $P\left(z_{t}^{i}=\right.$ 正常 $\mid z_{t}^{i}=$ 異常 $)=1.0 e^{-2}$ \\
& $P\left(z_{t}^{i}=\right.$ 異常 $\mid z_{t}^{i}=$ 正常 $)=1.0 e^{-4}$ \\
& $P\left(z_{t}^{i}=\right.$ 異常 $\mid z_{t}^{i}=$ 異常 $)=1.0$ \\
パラメータ遷移分布分散 & $V_{0}=10.0$ \\
& $V_{1}=0.01$ \\
スムージングパラメータ & $h=0.1$ \\
初期状態量の分散値 & $V\left(\boldsymbol{x}_{0}^{i}\right)=1.0 e^{-4}$ \\
状態遷移分布の分散值 & $1.0 e^{-6}(1 \sim 6), 1.0 e^{-9}(7 \sim 12)$ \\
観測分布の分散值 & $1.0 e^{-2}(1 \sim 3), 1.0 e^{-5}(4 \sim 9)$, \\
& $1.0 e^{-7}(10 \sim 12)$ \\
&
\end{tabular}

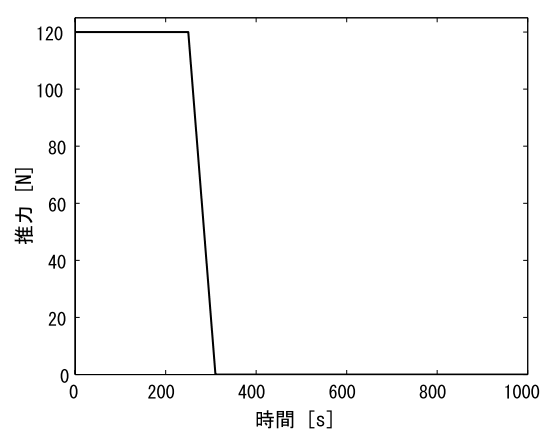

第 7 図＼cjkstart異常ケース (a) におけるスラスタ\#4 の推力低下

$r\left(P\left(z_{t}^{i}\right)=\right.$ 異常，正常 $)$ を $r\left(z_{t}^{i}=\right.$ 異常 $) \gg r\left(z_{t}^{i}=\right.$ 正常 $)$ として設定する必要がある . 各異常ごとに与えることも可 能であるが , 全異常モードのリスクは共通で一つ設定すれ ば十分である。またこの他に，(8) 式中の異常・正常時光 れ光れのパラメータ遷移分布の分散 $V_{0}, V_{1}, 4.1 .3$ 中に出 てくるパラメータ遷移時に加わるノイズの分散を調整する $h(>0)$ ，および推論に用いる状態遷移・観測分布の分散值 や初期時刻における状態量の平均値と分散値を設定する必 要がある .

次節の実験では，全異常ケース共通に，第 2 表に示すよ うにこれらのパラメータを設定した*12. またパーティクル 数は 10000 個であり, 状態量初期值の平均値はシミュレー ション初期值と同じ值に設定した .

5.3 実験結果と考察 実験では, スラスタが全壊に至 る異常，複杂隹な推力変化を伴うスラスタ異常，および微小 な推力低下が発生する異常の三つの場合について行った .

5.3.1 スラスタが全壊に至る異常ケース (a) 一つ目の 異常ケースとして，第 7 図のように，スラスタ\#4 か時刻 250 秒から 60 秒間かけて推力を完全に失う異常に対し，提 案手法を適用した結果を示す。

まず第 8 図は, 各スラスタの異常確率の推移を, 全スラ スタが正常である確率の推移と共に図示したものである . つまり, $P\left(z_{t}^{i}=\right.$ 異常 $)(i=1, \cdots, 14)$ および $P\left(z_{t}^{1}=\right.$ 正常 $, \cdots, z_{t}^{14}=$ 正常) について図示したものである . 図か

*12 ただし異常モード遷移確率に関しては，比のみが有意であるので， 表中の確率は 1 に正規化されていない. また遷移・観測分布の分 散值の括弧内の数字は, 状態量の次元 $(1 \sim 3:$ 変位, $4 \sim 6$ : 速度, 7〜9: 姿勢角，10〜12: 各速度) を表す。

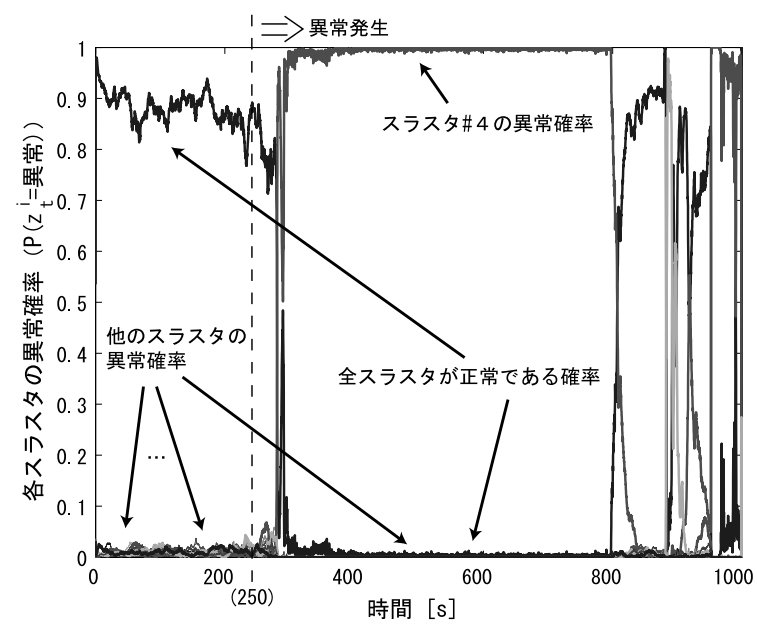

第 8 図＼cjkstart異常ケース (a) における異常確率の推移

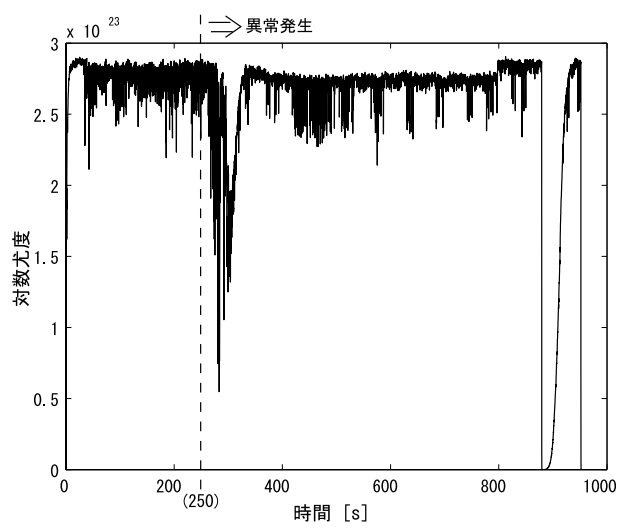

第 9 図 異常ヶース (a) における予測尤度の推移

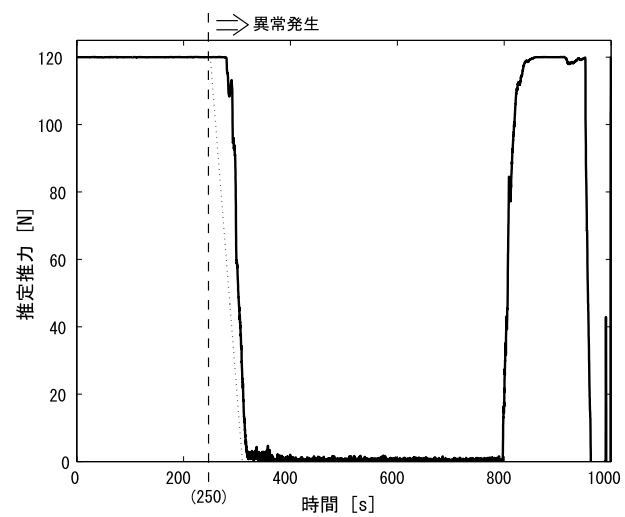

第 10 図 異常ケース (a) における推定推力の推移

らわかるように, 異常発生後しばらくして (40 秒程度)，急 激に正常である確率が減少し, 逆に $P\left(z_{t}^{4}=\right.$ 異常 $)$ が増加 している、なおこの 40 秒間には, 推力がまだ完全に失われ ているわけではなく，また観測やコマンド系列も正常時と の差異がほとんどないため , 単に観測とコマンド入力のみ を監視しているだけでは検知は極めて困難である . 本手法 では，この時間内に異常個所の特定も実現している．また 第 9 図は, この異常における予測尤度の推移を図示したも のであるが, ほぼ異常発生直後に減少が見られるため, 異 


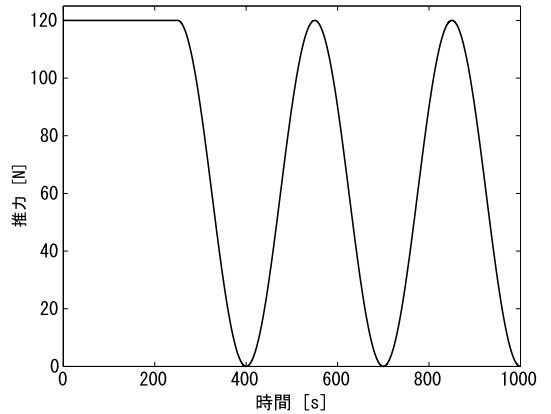

第11図 異常ケース (b) におけるスラスタ\#4 の推力低下

常検知のみであればこの推移を監視することで，より迅速 に可能となる. 光して第 10 図は, 異常が発生したスラス タ\#4 の推定推力である. 異常時のパラメータが, やや時 間遅れを伴うものの，正確に推定されていることがわかる . なお，いずれも時刻 800 秒以後は複雑な変動を示している が，これはこの時点で既に宇宙機が完全に制御不能になっ ているためである .

5.3.2 複雑な推力変化を伴う異常ヶース (b) 二つ目の 異常ケースとして，第 11 図に示すように，時刻 250 秒か ら 300 秒周期の $\sin$ 波状の複雑な推力変化を伴う異常ヶー スに対して適用した結果を示す。

まず第 12 図は, 第 8 図同樣, 各スラスタの異常確率 と全スラスタが正常である確率の推移を図示したもので ある.第 11 図の推力変化と連動して, 正常時からの偏差 が大きい時間帯は，すべてのスラスタが正常である確率 $P\left(z_{t}^{1}=\right.$ 正常, $\cdots, z_{t}^{14}=$ 正常 $)$ が大きく減少し，逆にスラ スタ\#4 が異常である確率 $P\left(z_{t}^{4}=\right.$ 異常 $)$ がほぼ 1 付近ま で増加している.また，第 13 图は第 9 图同樣に予測尤度の 推移を図示したものであり，第 14 図は第 10 図同樣に異常 スラスタの推定推力である . 前異常ヶースでも光うであっ たが, 予測尤度の推移は, 第 13 図に示されるように, 異常 発生直後 (正常からの偏差の拡大開始時) に大きく低下す ることがわかる. 弚して产の後, 第 12 図の各スラスタの異 常確率や第 14 図のパラメータ推定値が, やや時間遅れを 伴って真值に近づくにつれ，予測尤度は再び元の值に戻っ ていることがわかる. 本ケースでも , 時刻 900 秒後半以降 は宇宙機が制御不能となっている。

5.3.3 微小な推力低下が発生する異常ケース (c) もう 一つの異常ケースとして，第 15 図のように , 時刻 250 秒か ら規定推力の $70 \%$ へ推力が低下する異常ケースに関する適 用結果を示す. 本ケースは, 前二つのケースに比べて異常 の規模が小いため, 状態の正常時との差異が小さく, 異 常検知や診断は極めて難しいケースであると言える .

まず第 16 図は, これまで同樣, 各スラスタの異常確率と 全スラスタが正常である確率の推移を图示したものである . 前述のように本ケースは比較的難しい異常ヶースであるた め,これまでに比べて明確な結果ではないが, 図のように 異常発生後明らかにスラスタ\#4の異常確率が増加してい る.第 17 図は予測尤度の推移であるが, 異常発生直後に微

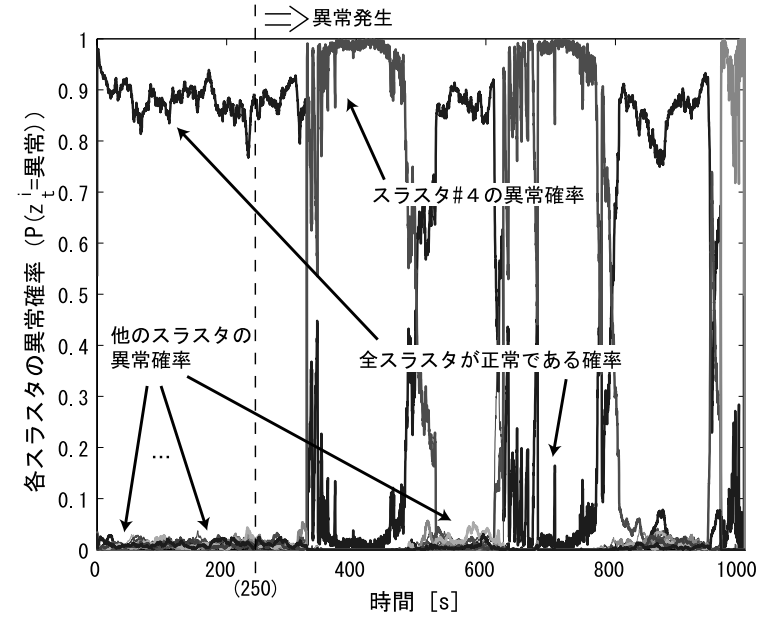

第 12 図 異常ヶース (b) における異常確率の推移

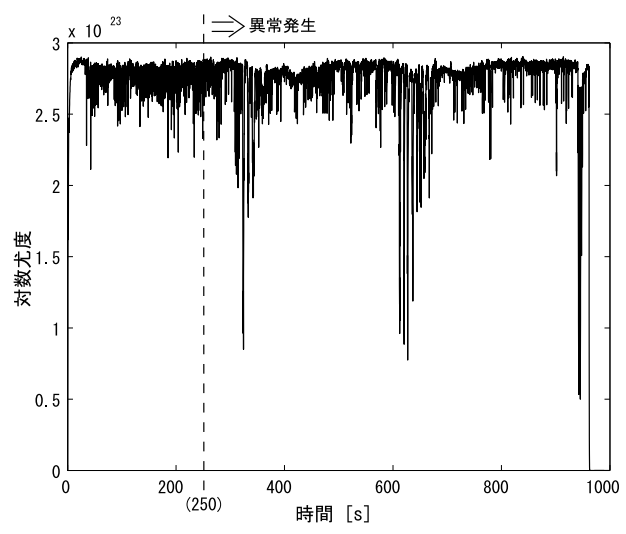

第13 図 異常ケース (b) における予測尤度の推移

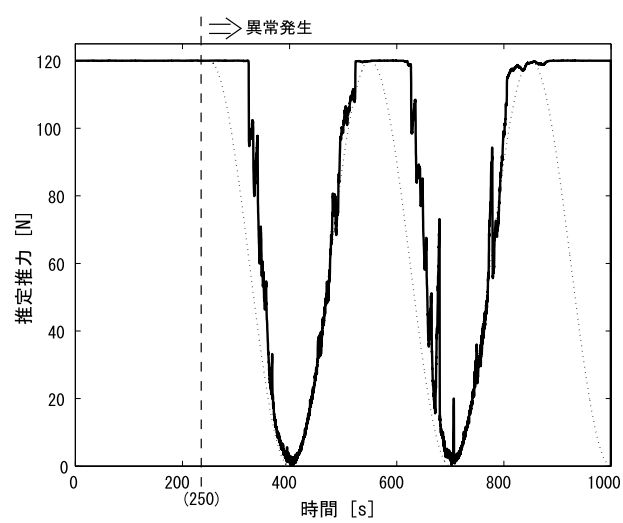

第14図＼cjkstart異常ケース (b) における推定推力の推移

小な低下が見られるものの, 前ケースに比べると产の変化 は小さい .しかし，第 18 図に示すように, 異常スラスタの 推定推力は, 正確な推定が可能であることがわかる.なお 本ケースに関しては, 全パーティクルを用いた推定値に加 え， $P\left(z_{t}^{4}=\right.$ 異常 $)$ であるパーティクルのみを用いた場合 の推定値を同時に图示している.

\section{6. 結論}

本稿では, システムを記述するパラメータと，光のパラ 


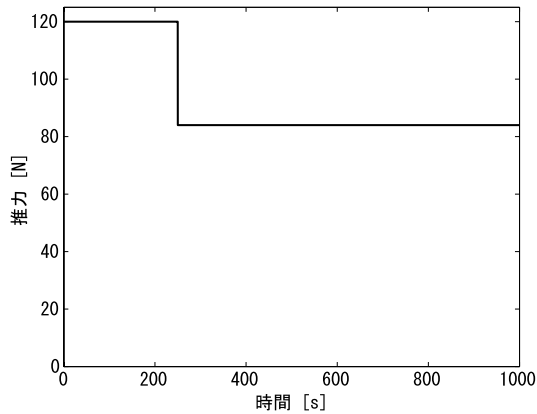

第15図＼cjkstart異常ヶース (c) におけるスラスタ\#4 の推力低下

メータの変化を決める異常モードとをリアルタイムで同時 に推定することにより，異常検知および異常診断を行うた めのアルゴリズムを提案した . 提案した異常診断法は, 定 量モデルベース診断の枠組みの一つであるパラメータ推定 法を，確率推論問題として扱ったものと考えることができ， システムの不確実性に対してロバストであり，更にリアル タイムでの実行が可能な枠組みとなっている.本研究では， パラメータ推定を伴う確率推論へ逐次モンテカルロ法を適 用する際に問題となる，探索空間の増大と異常の低確率性 に対して，異常の独立性を明示的に利用可能な異常モード， その異常モード上のリスク, およびパラメータ推定のため のカーネル平滑化を導入することにより, 迅速な異常検知 と異常診断を実現するアルゴリズムを提案した . 更に本稿 では, 宇宙機のランデブー・プロセスにおけるスラスタ異 常を模擬したシミュレーション・データを用いて，提案す る異常診断アルゴリズムの検証実験を行い, 光の有用性を 確かめた .

提案したアルゴリズムは，対象とするシステムを記述す る推論モデルを事前に与える必要がある．しかし場合によっ ては，対象に関する知識が乏しかったり，あるいは対象の 不確実性が高く，事前に正確なモデルを与えることが困難 となることが考えられる，乥のような場合には，対象から 得られたデータを用いてシステムを記述するモデルを獲得 する学習 (同定) 手法を用いる必要がある . 今後, 提案する 異常診断手法をこのような学習手法と組み合わせ，知識が 乏しかったり不確実性の高い対象に対しても適用可能な異 常診断の枠組みを構筑していく予定である。

本研究を進めるにあたり，宇宙航空研究開発機構 (JAXA) の山中浩二氏 , 稲場典康氏には, 専門家の立場から樣々な 知見や情報を頂きました．深く感謝いたします．

\section{参 考 文 献}

1) Tallo, D. P., Durkin, J. and Petrik, E. J.: Intelligent Fault Isolation and Diagnosis for Communication Satellite Systems, Telematics and Informatics, 9 (1992), pp. 173-190.

2) Ciceri, F. and Marradi, L.: Event Diagnosis and Recovery in Real-Time On-Board Autonomous Mission Control, Proc. of the 1st Ada-Europe Symp., 1994.

3) Nishigori, N., Hashimoto, M., Choki, A. and Mizutani, M.: Fully Automatic and Operator-Less Anomaly Detecting Ground Support System for Mars Probe 'NOZOMI,' Proc.

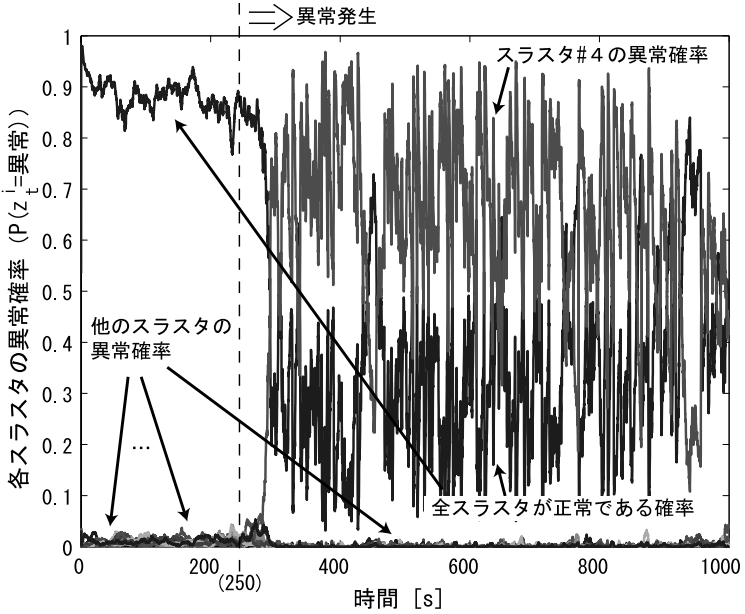

第16 図 異常ケース (c) における異常確率の推移

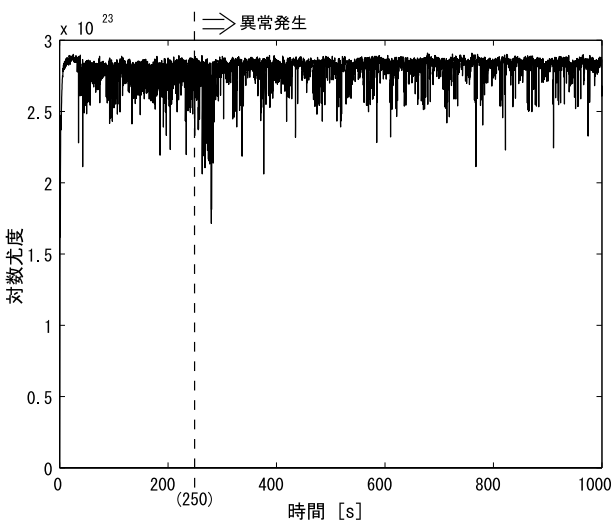

第 17 図 異常ケース (c) における予測尤度の推移

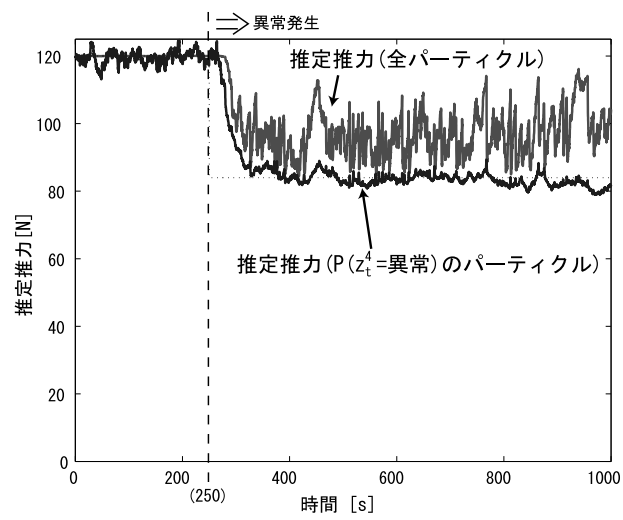

第 18 図 異常ケース (c) における推定推力の推移

of the 6th Int. Symp. on Artificial Intelligence and Robotics and Automation in Space (I-SAIRAS 2001), 2001.

4) Muscettola, N., Nayak, P. P., Pell, B. and Williams, B. C.: Remote Agent: To Boldly Go Where No AI System Has Gone Before, Artif. Intell., 103 (1998), pp. 5-48.

5) Williams, B. C. and Nayak, P. P.: A Model-Based Approach to Reactive Self-Configuring Systems, Proc. of the 13th National Conf. on Artificial Intelligence and Eighth Innovative Applications of Artificial Intelligence Conf., 1996.

6) Jensen, F. V., Kjaerulff, U. and Kristiansen, B.: The SACSO Methodology for Troubleshooting Complex Systems, Artificial Intelligence for Engineering Design, Analysis and Manu- 
facturing (AIEDAM), 15 (2001), pp. 321-333.

7) Deaden, R., Willeke, T. and Hutter, F.: Real-Time Fault Detection and Situational Awareness for Rovers: Report on the Mars Technology Program Task, Proc. of IEEE Aerospace Conf., 2004.

8) 河原吉伸, 矢入健久, 町田和雄 : Dynamic Bayesian Networks を用いた宇宙機異常診断法, 人工知能学会論文誌, 21 (2006), pp. 45-54.

9) Takadama, K., Murakami, T. and Kawahara, Y.: Detecting Failure of Spacecraft Using Separated States in Particle Filters, Proc. of the 25th Int. Symp. on Space Technology and Science (ISTS 2006), 2006.

10) Horvath, G., Ingham, M., Chung, S., Martin, O. and Williams, B.: Practical Application of Model-Based Programming and State-Based Architecture to Space Missions, Proc. of the 2nd IEEE Int. Conf. on Space Mission Challenges for Information Technology (SMC-IT 2006), 2006.

11) Julier, S. J. and Uhlmann, J. K.: A New Extension of the Kalman Filter to Nonlinear Systems, Proc. of AeroSense: The 11th Int. Symp. on Aerospace/Defence Sensing, Simulation and Controls, 1997.

12) Doucet, A., de Freitas, N. and Gordon, N.: Sequential Monte Carlo Methods in Practice, Statistics for Engineering and Information Science, Springer, Berlin, 2001.

13) Arulampalam, M. S., Maskell, S., Gordon, N. and Clapp, T.:
A Tutorial on Particle Filters for Online Nonlinear/NonGaussian Bayesian Tracking, IEEE Trans. Signal Proc., 50 (2002), pp. 174-188.

14) Pitt, M. and Shephard, N.: Filtering via Simulation: Auxiliary Particle Filters, J. Am. Statist. Assoc., 94 (1999), pp. 590-599.

15) Isermann, R.: Model-Based Fault-Detection and DiagnosisStatus and Applications, Ann. Rev. Control, 29 (2005), pp. 71-85.

16) Venkatasubramanian, V., Rengaswamy, R., Yin, K. and Kavuri, S. N.: A Review of Process Fault Detection and Diagnosis Part I-III, Comput. Chem. Eng., 27 (2003), pp. 293-346.

17) Murphy, K. P.: Dynamic Bayesian Networks: Representation, Inference and Learning, Doctoral Thesis, California Univ., 2002.

18) Thrun, S., Langford, J. and Verma, V.: Risk Sensitive Particle Filters, Advances in Neural Information Processing Systems 14, MIT Press, Conbridge, London, 2002.

19) West, M.: Approximating Posterior Distributions by Mixtures, J. Royal Statist. Soc., 55 (1993), pp. 409-422.

20) West, M.: Mixture Models, Monte Carlo, Bayesian Updating and Dynamic Models, Computing Science and Statistics, Newton, J. H., ed., Interface Foundation of North America, Fairfax Station, Virginia, 1993, pp. 409-422. 